\title{
Canadian Civil Justice: Relief in Small and Simple Matters in an Age of Efficiency
}

\author{
Jonathan Silver \& Trevor C.W. Farrow*
}

\begin{abstract}
Canada is in the midst of an access to justice crisis. The rising costs and complexity of legal services in Canada have surpassed the need for these services. This article briefly explores some obstacles to civil justice as well as some of the court-based programmes and initiatives in place across Canada to address this growing access to justice gap. In particular, this article explains the Canadian civil justice system and canvasses the procedures and programmes in place to make the justice system more efficient and improve access to justice in small and simple matters. Although this article does look briefly at the impact of the global financial crisis on access to justice efforts in Canada, we do not provide empirical data of our own on this point. Further, we conclude that there is not enough existing data to draw correlations between austerity measures in response to the global crisis and the challenges facing Canadian civil justice. More evidence-based research would be helpful to understand current access to justice challenges and to make decisions on how best to move forward with meaningful innovation and policy reform. However, there is reason for optimism in Canada: innovative ideas and a national action plan provide reason to believe that the country can simplify, expedite, and increase access to civil justice in meaningful ways over the coming years.
\end{abstract}

Keywords: Canada, small and simple matters, austerity, civil justice, access to justice

Canada is simultaneously trending negatively and positively in its delivery of civil justice. A growing gap between legal needs and the affordability and availability of legal services threatens access to justice for many Canadians. At the same time, however, provinces and territories are implementing a number of programmes aimed at expediting and streamlining dispute resolution in small and simple civil matters. In this article, we address both of these trends. Our research question is simple: what reforms and initiatives are available in Canada to close the gap between legal needs and the costs and complexity of legal services? While it is beyond the scope of our research to evaluate the relative merits of all of these Canadian initiatives, we provide some information on the efficacy and popularity of these programmes where data are available. We also briefly highlight the current push for greater efficiency in civil justice, along with some implications of global austerity on these initiatives, but we do not focus extensively on efficiency or austerity measures. As will be explained, without the benefit of strong empirical data, which is required, it is difficult to draw correlations between global austerity and changes in Canadian civil justice in an efficiency-based access to justice landscape.

This article started as a summary report on the status of Canadian simplified civil procedures for the $2015 \mathrm{XV}$ World Congress of Procedural Law and grew into a more fulsome research project on Canadian civil justice. Our goal in this article is to provide an overview of Canada's approach to relief in small and simple civil matters, to draw connections between programmes in place across Canada primarily aimed at creating a more efficient legal system, and - by doing so - to assist current efforts designed to address the very challenging but important project of improving the accessibility of civil justice. This article proceeds as follows. In Part 1, we provide a background of the Canadian civil justice system and outline some of the challenges it faces. In Part 2, we detail specific mechanisms and programmes for relief in small and simple matters, including: (i) simplified procedures and fast track litigation; (ii) summary judgement and special cases; (iii) summary trials; (iv) small claims courts; and (v) court-based alternative dispute resolution. In Part 3, we conclude with observations about the delivery of civil justice in small and simple matters in the future.

\section{The Canadian Context}

In order to contextualise our discussion of simplified procedures in Canada, we explain three inter-related aspects of the Canadian civil justice system. First, we explain the constitutional and legal framework of civil justice, with particular emphasis on the division of jurisdiction over civil matters. Second, we outline the state of access to justice in Canada and some of the impacts of the global financial crisis on Canada. Finally, we explain overarching principles of civil justice in Canada that aim to achieve fair and expedient dispute resolution. 


\subsection{The Legal Framework of Civil Justice in Canada}

Canada is a federal state with constitutionally empowered provincial and federal governments. All of the Canadian provinces follow the common law tradition, except for Québec, which derives its origins from Civil Law.

As we have explained elsewhere, ${ }^{1}$ responsibility for the administration of civil justice and civil courts in Canada is split between the provincial and federal governments. The Constitution Act, 1867 grants provincial governments legislative authority over 'the administration of justice in the province' and 'Procedure in Civil Matters' in provincial courts. ${ }^{2}$ Therefore, procedural law and simplified procedures vary from province to province.

Civil matters are typically heard in provincial Superior Courts, which are also known as section 96 courts based on their enumeration in the Constitution Act, $1867 .^{3}$ These provincial courts are courts of 'inherent jurisdiction' and have broad jurisdiction to hear most matters. ${ }^{4}$ Responsibility for Superior Courts is split between the federal and provincial governments. The Supreme Court of Canada ('Supreme Court') recently explained this split jurisdiction: 'While the federal government is responsible for the appointment of s. 96 judges ... the provincial legislatures enact laws and adopt regulations pertaining to courts, rules of court and civil procedure, or delegate this function to another body.' 5

Although procedural law may diverge across provinces, Canada's uniform court system ensures a certain level of consistency. The Supreme Court has jurisdiction to hear appeals on all matters from the appellate courts across the country, and its decisions are binding nationwide. ${ }^{6}$ Even if an appeal is decided in the context of a legislative regime found in only one province, the principles underlying the Supreme Court's judgements influence the interpretation of all procedural codes and laws. Nevertheless, there is no right of appeal to the

1. J. Silver and T.C.W. Farrow, Interim Relief in Canadian Courts (2015), at 1-2 [unpublished].

2. Constitution Act, 1867 (UK), 30 \& 31 Vict., c 3, s. 92(14), reprinted in RSC 1985, App II, No. 5 [Constitution Act, 1867]. See also Ontario v. Criminal Lawyers' Association of Ontario, 2013 SCC 43, paras. 32-33, [2013] 3 SCR 3 [Criminal Lawyers' Association].

3. Constitution Act, 1867, above n. 2, s 96. This constitutional provision gives authority to the Governor General (on the advice of the Cabinet of the federal government) to select judges to sit in provincial Superior Courts. Canada also has Federal Courts, but these are statutory courts with specific jurisdiction over matters delegated to them, such as Intellectual Property and Maritime law. The majority of civil proceedings occur in the Superior Courts, but for more information of Federal Courts in Canada, see Federal Court of Canada, 'About the Court' (2012), available at: <http://cas-ncr-nter03.cas-satj.gc.ca/portal/page/portal/ fc_cf_en/About>.

4. MacMillan Bloedel Ltd v. Simpson, [1995] 4 SCR 725, para. 38, 130 DLR (4th) 385 (these courts have 'those powers which are essential to the administration of justice and the maintenance of the rule of law').

5. Criminal Lawyers' Association, above n. 3, paras. 32-33. For a more detailed description of Superior Courts in Canada and their role, see T.C.W. Farrow, Civil Justice, Privatization, and Democracy (Toronto: University of Toronto Press) (2014), at 13-50.

6. Supreme Court Act, RSC 1985, c S-26, s 35. See also Ontario (Attorney General) v. Pembina Exploration Canada Ltd., [1989] 1 SCR 206, para. 14, 57 DLR (4th) 710
Supreme Court in civil cases, and the Court only grants leave to appeal in cases that raise issues of public or national importance. ${ }^{7}$ As a result, many provincial appellate courts have primary responsibility for the interpretation of many province-specific procedural laws and systems.

Given that each province is constitutionally responsible for administering civil justice, provincial governments diverge in their response to and engagement with issues of access to justice. As we discuss below, Canada faces an access to justice crisis, and coordination between provinces is needed to implement a countrywide access to justice strategy.

\subsection{Canada's Access to Justice Crisis and} Response to the Global Financial Crisis

Much has been written on the state of access to justice in Canada. ${ }^{8}$ The Supreme Court recently diagnosed Canada's problem: 'Ensuring access to justice is the greatest challenge to the rule of law in Canada today ... ordinary Canadians cannot afford to access the adjudication of civil disputes. ${ }^{9}$ While it is beyond the scope of this article to detail exhaustively the access to justice challenges in Canada, some discussion of this issue is necessary to contextualise the need for affordable and simplified justice solutions. At the end of this section, we also briefly consider the impact of the global financial crisis and austerity measures on these access issues in Canada.

We note at the outset that there is a major lack of empirical data on issues of access to justice in Canada, which is a shared concern internationally as well. As such, research on civil justice in Canada is not without significant challenges. As several recent reports have indicated, there is a significant and growing need for evidence-based research in all areas of civil and family jus-

7. Supreme Court Act, above n. 6, s 40(1); MacDonald v. City of Montreal [1986] 1 SCR 460, para. 141, 27 DLR (4th) 321. See also $R$ v. Shea, 2010 SCC 26, para. 9, [2010] 2 SCR 17.

8. See e.g. Canadian Bar Association Access to Justice Committee, Reaching Equal Justice Report: An Invitation to Envision and Act (Ottawa: Canadian Bar Association) (2013), available at: <www.cba.org/CBA/ equaljustice/secure_pdf/EqualJusticeFinalReport-eng.pdf>; Canadian Forum on Civil Justice, The Costs of Justice: Weighing the Costs of Fair \& Effective Resolution to Legal Problems (Toronto: Canadian Forum on Civil Justice) (2012), available at: <www.cfcj-fcjc.org/sites/default/files/ docs/2012/CURA_background_doc.pdf >; Action Committee on Access to Justice in Civil and Family Matter, Access to Civil \& Family Justice: A Roadmap for Change (Ottawa: Action Committee on Access to Justice in Civil and Family Matter) (2013), available at: <www.cfcj-fcjc.org/ sites/default/files/docs/2013/AC_Report_English_Final.pdf>; T.C.W. Farrow, 'What is Access to Justice?', 51(3) Osgoode Hall Law Journal 957 (2014). For more general resources, see Canadian Forum on Civil Justice, available at: <www.cfcj-fcjc.org/>

9. Hryniak v. Mauldin, 2014 SCC 7, paras. 1, 24, [2014] 1 SCR 87. 
tice. ${ }^{10}$ Nevertheless, it is clear that the growing gap between legal needs and affordable legal services remains the most pressing barrier to civil justice in our country. The Canadian Bar Association, relying on empirical studies, ${ }^{11}$ concluded in a recent report that 'over the course of a lifetime almost everyone will confront a justiciable problem'. ${ }^{12}$ Yet, increasing legal costs have made legal services inaccessible to many Canadians. ${ }^{13}$ Only $6.7 \%$ of people with legal issues use formal court or tribunal systems. ${ }^{14}$ On average, lawyers in Canada bill from $\$ 218$ to $\$ 394$ an hour, depending on the seniority of counsel and the jurisdiction of practice. ${ }^{15} \mathrm{~A}$ 3 -day civil trial may cost over $\$ 60,000 .{ }^{16}$ In comparison, the 2011 average family income after tax in Canada was $\$ 79,600$ and the average individual income after tax was $\$ 31,400 .{ }^{17}$ The prevalence of everyday legal challenges and the unaffordability of legal services underscore the increasing need for access to less expensive simplified procedures.

The complexities and time-intensive nature of even basic legal procedures also plague Canadian civil justice. The Action Committee on Access to Justice in Civil and Family Matters ('Action Committee') explained that 'formal procedures seem to grow ever more complicated and disproportionate to the needs of the litigants and the matters involved' ${ }^{18}$ One judge, writing extra-judicially, commented that the rapid decline of the tradi-

10. See e.g. Civil Non-Family Cases Filed in the Supreme Court of BC: Research Results and Lessons Learned, A report prepared by Focus Consultants for the Canadian Forum on Civil Justice (Victoria, BC: Canadian Forum on Civil Justice) (2015), at 24-31; Action Committee on Access to Justice in Civil and Family Matters, above n. 8, at 23. See also $M$. Jerry McHale (for Canadian Forum on Civil Justice), 'Access to Justice Reform and the Data Deficit - Some Lessons Learned', SLAW, 25 November 2015, available at: <www.slaw.ca/2015/11/25/access-to -justice-reform-and-the-data-deficit-some-lessons-learned/>; J. Currie 'Access to Justice, Access to Clients: Methodological Challenges in Civil Justice Research', A2J Blog, 18 February 2015, available at: <www.cfcjfcjc.org/a2jblog/access-to-justice-access-to-clients-methodologicalchallenges-in-civil-justice-research>.

11. See A. Currie, The Legal Problems of Everyday Life: The Nature, Extent and Consequences of Justiciable Problems Experienced by Canadians (2009), available at: <www.justice.gc.ca/eng/rp-pr/csj-sjc/jsp-sjp/rr07_ la1-rr07_aj1/rr07_la1.pdf>. See also Y. Taddese, 'Legal Pains: The Cost of Justice Includes Physical Health', Canadian Lawyer Magazine, 15 March 2015, available at: <www.canadianlawyermag.com/legalfeeds/ 2587/legal-pains-the-cost-of-justice-includes-physical-health.html>;

'Everyday Legal Problems and the Cost of Justice in Canada', A2J Blog, 12 March 2015, available at: <www.cfcj-fcjc.org/a2jblog/everyday-legal -problems-and-the-cost-of-justice-in-canada>

12. Canadian Bar Association Access to Justice Committee, above n. 8, at 8 .

13. Action Committee on Access to Justice in Civil and Family Matters, above n. 8, at 3.

14. 'Everyday Legal Problems and the Cost of Justice in Canada', A2J Blog, 12 March 2015, available at: <www.cfcj-fcjc.org/a2jblog/everyday-legal -problems-and-the-cost-of-justice-in-canada>.

15. M. McKiernan, 'The Going Rate', Canadian Lawyer Magazine, 33 at 35 (2014), available at: <www.canadianlawyermag.com/images/stories/ pdfs/Surveys/2014/cljune14legalfees.pdf>.

16. Ibid., at 36. See also T. Tyler, 'A 3-Day Trial Likely to Cost You $\$ 60,000 '$, Toronto Star, 3 March 2007, available at: <www.thestar. com/news/2007/03/03/a_3day_trial_likely_to_cost_you_60000.html $>$. Of course, the costs of legal services greatly vary from province to province and city to city.

17. Statistics Canada, 'Average Income after Tax by Economic Family Types (2007-2011)', 27 June 2013, available at: <www.statcan.gc.ca/tablestableaux/sum-som/l01/cst01/famil21a-eng.htm>. tional trial is often attributed to the 'significant time delay and cost associated with litigation process'. ${ }^{19}$ The Ontario Civil Fustice Reviem in 1995 further suggested that '[f]rom wasteful motions through endless discovery to long waiting for pre-trials, trials and appeals, the public perceives the civil justice system to be out of control'. ${ }^{20}$ These comments are as relevant today, as they were 20 years ago.

A consequence of Canada's inaccessible civil justice system has been the increase of self-represented litigants. Nearly $50 \%$ of those surveyed in Canada in 2008 reported that they try to solve their legal problems on their own, without resort to legal advice. ${ }^{21}$ Thus, when issues materialise in court, these individuals often go it alone. A recent study on self-represented litigants in Canada concluded that, in some circumstances, self-represented litigants 'may amount to more than half of the litigants in today's courtrooms'. ${ }^{22}$

Although there is a deficiency of empirical data on the incidence of self-representation, a study from British Columbia demonstrates an upward trend. From 1999 to 2001, between $5.5 \%$ and $14.2 \%$ of litigants in the British Columbia trial court were self-represented. By 2011, $21 \%$ of litigants in general civil matters were without representation. ${ }^{23}$ In other courts, particularly in the family law context, the numbers are typically much higher. The most common reason that individuals choose to self-represent is their inability to afford legal counsel. ${ }^{24}$ Despite valuable efforts taking place in Canada to address this issue, ${ }^{25}$ self-representation remains a significant concern.

18. Action Committee on Access to Justice in Civil and Family Matters, above n. 8, at 7 .

19. Honourable C.L. Campbell, 'Managing the Civil Process', 32(2) Advocates' Society Journal 9, at 9 (2013).

20. Honourable R.A. Blair and S. Lang, Civil Justice Review: First Report (Toronto: Queen's Printer for Ontario) (1995), at 126, available at: $<$ www.attorneygeneral.jus.gov.on.ca/english/about/pubs/cjr/ firstreport/default.asp $>$

21. A. Currie, 'Self-Helpers Need Help Too', 9 August 2010, available at: $<w w w$.lawforlife.org.uk/research-and-theory/self-helpers-need-helptoo/>; Action Committee on Access to Justice in Civil and Family Matters, above n. 8 , at 4 .

22. T.C.W. Farrow et al., 'Addressing the Needs of Self-Represented Litigants in the Canadian Justice System: A White Paper Prepared for the Association of Canadian Court Administrators', 27 March 2012, at 16, available at: <www.cfcj-fcjc.org/sites/default/files/docs/2013/Address ing $\% 20$ the $\% 20$ Needs $\% 20$ of $\% 20$ SRLs $\% 20$ ACCA $\% 20$ White $\% 20$ Paper \%20March\%202012\%20Final\%20Revised\%20Version.pdf>.

23. J. MacFarlane, The National Self-Represented Litigants Project: Identifying and Meeting the Needs of Self-Represented Litigants (Final Report) (Kingsville, ON: Treasurer's Advisory Group on Access to Justice (TAG) Working Group Report) (2013), at 34-5, available at: <www.lsuc. on.ca/uploadedFiles/For_the_Public/About_the_Law_Society/ Convocation_Decisions/2014/Self-represented_project.pdf>. In foreclosure proceedings in British Columbia, 19\% of litigants are unrepresented, and in bankruptcy proceedings, $34 \%$ are without counsel (Ibid.). Macfarlane reports similar numbers of self-represented litigants in Alberta and Ontario (Ibid.).

24. Ibid., at 39 .

25. See e.g. Ibid.; R. Mendleson, 'Can't Afford a Lawyer? How Courtroom Innovations Help Self-Represented Litigants', Toronto Star, 21 March 2015, available at: <www.thestar.com/news/crime/2015/03/21/cantafford-a-lawyer-how-courtroom-innovations-help-self-representedlitigants.html> (describing a programme where law students coach selfrepresented litigants in Windsor, Ontario). 
The limited availability of publically funded legal aid services has further exacerbated the growing civil justice gap in Canada. Direct government spending on legal aid services has declined by over $20 \%$ since the early 1990s. ${ }^{26}$ This decline has coincided with decreases in funding for legal aid by the federal government. ${ }^{27}$ Even where funding is available, legal aid is only available to those whose incomes are well below average. ${ }^{28}$ For example, in Manitoba, free legal assistance is only available to individuals whose gross annual income is $\$ 14,000$ or under. ${ }^{29}$ In Nova Scotia, legal aid is only available to those who are on or who can qualify for Income Assistance.$^{30}$ Furthermore, only limited types of legal services are available through legal aid. ${ }^{31}$

Nevertheless, there are some positive trends in Canadian legal aid funding. While overall spending is down since the mid-1990s, government spending on legal aid funding increased by $13.6 \%$ from 2007-2008 to 2011-2012. ${ }^{32}$ In 2014, e.g. the Ontario government committed close to $\$ 100$ million to legal aid, increasing the threshold for legal aid eligibility for the first time since $1996 .{ }^{33}$ Furthermore, while the 2015 federal budget offered little increased justice spending, ${ }^{34}$ the 2014 federal budget included increased funding for an Aboriginal Justice Strategy and the increased appointment of judges in Alberta and Québec to 'ensure that cases are heard in a timely manner' ${ }^{35}$ In addition, much justicerelated funding (infrastructure, legal aid, administra-

26. A. Currie, 'The State of Civil Legal Aid in Canada: By the Numbers in 2011-2012', A2J Blog, 13 May 2013, available at: <www.cfcj-fcjc.org/ commentary/the-state-of-civil-legal-aid-in-canada-by-the-numbers-in -2011-2012\#sthash.mruQ1mAj.dpuf>

27. Canadian Bar Association Access to Justice Committee, above n. 8, at 9.

28. Action Committee on Access to Justice in Civil and Family Matters, above n. 8, at 3-4.

29. Legal Aid Manitoba, 'Who Qualifies Financially', 19 March 2015, available at: <www.legalaid.mb.ca/getting-legal-aid/who-qualifies-financial ly>.

30. Nova Scotia Legal Aid Commission, 'Do I Qualify?', 2010, available at: $<$ www.nslegalaid.ca/qualify.php>. Income assistance is Nova Scotia's welfare programme. See 'Income Assistance', 23 October 2013, available at: <http://novascotia.ca/coms/employment/income_assistance/ index.html>.

31. Action Committee on Access to Justice in Civil and Family Matters, above n. 8, at 3-4.

32. Currie, above n. 26

33. Ministry of the Attorney General, News Release, 'Giving More Ontarians Access to Affordable Legal Services: Province Doubling Number of People Eligible for Legal Aid', 30 October 2014, available at: <http:// news.ontario.ca/mag/en/2014/10/giving-more-ontarians-access-toaffordable-legal-services.html>. See also C. Goar, 'Against All Odds, Legal Aid Ontario Is Getting Better: Goar', Toronto Star, 26 March 2015, available at: <www.thestar.com/opinion/commentary/2015/03/ 26/against-all-odds-legal-aid-ontario-is-getting-better-goar.html>

34. J. Ling, 'Budget 2015: Little for Rising Justice Costs', National Magazine, 21 April 2015, available at: <www.nationalmagazine.ca/Blog/April -2015/Budget-2015-Little-for-rising-justice-costs.aspx>.

35. S. Bell, 'Justice Programs in the 2014 Federal Budget', Precedent Magazine, 18 February 2014, available at: <http://lawandstyle.ca/law/2014federal-budget-justice-programs/>; 'Providing Additional Judges' (2014), available at: <http://actionplan.gc.ca/en/initiative/providingadditional-judges>; C. Santry, '\$4.4 Million in Budget for Six New Judges', Canadian Lawyer Magazine, 12 February 2014, available at: <www. canadianlawyermag.com/legalfeeds/1936/4-4-million-in-budget-for-six -new-judges.html>. tion, etc.) comes from provincial government budgets, which are different across the country.

In the face of these recent developments, it is unclear whether underfunding of Canadian legal services relates to the pressures of post-financial crisis global austerity. Although austerity is not a primary focus of this article, a few brief observations will help add context to the Canadian position. Many of Canada's access to justice challenges pre-date the global financial crisis, and Canada's emergence from the global financial crisis is often 'deemed a success story'. ${ }^{36}$ The federal government was in a strong financial position at the outset of the global financial crisis - Canada's government posted a budget surplus in each year from 1997 to $2008 .{ }^{37}$ Moreover, for various reasons, ${ }^{38}$ Canada's banks were considered more resilient to the crisis than banks in other countries. ${ }^{39}$ Canada did not fully embrace austerity measures at the outset of the crisis. Based partly on the factors mentioned above and to avoid slow economic growth, the government's 'approach to austerity appears comparatively more balanced than that which can be observed elsewhere'. ${ }^{40}$ Through the past several years, Canada's federal debt has increased to over $\$ 600$ billion, ${ }^{41}$ and many provincial legislatures have also accumulated significant debts. ${ }^{42}$

While many have heralded Canada's emergence from the global financial crisis, other commentators and organisations have been more critical of Canada's economic outlook and policy. ${ }^{43}$ Since posting consecutive deficits in the post-recession period, the federal government, which radically changed (from Conservative to Liberal) in Canada's recent October 2015 federal election, continues to be committed ultimately to balancing the budget - although with promises of major increases

36. I. Roberge, 'New Development: Canada's Cutback Management', 34(2) Public Money \& Management 131, at 132 (2014).

37. For a detailed examination of how Canada achieved its strong financial position, see D.R. Henderson, 'Canada's Budget Triumph', 23(3) Journal of Applied Corporate Finance 8 (2011).

38. G. Isfeld, 'Canada's Banks Shake Off Global Sector Crisis', National Post, 10 October 2012, available at: <http://business.financialpost.com/ news/fp-street/canadas-banks-shake-off-global-sector-crisis>

39. K. Lynch, 'Avoiding the Financial Crisis: Lessons from Canada', Policy Options, May 2010, available at: <http://policyoptions.irpp.org/issues/ the-fault-lines-of-federalism/avoiding-the-financial-crisis-lessons-fromcanada/> Although, the banks did receive a large amount of funding (around $\$ 114$ billion) from the federal government during the crisis. See J. Greenwood, 'Was Canadian Banks' 'Secret' Bailout Really a Secret?', National Post, 30 April 2012, available at: <http://business. financialpost.com/uncategorized/canadas-secret-bank-bailout>.

40. Roberge, above n. 36, at 132.

41. Office the Parliamentary Budget Officer, 'Pre-Budget Outlook', 24 April 2015, available at: <www.pbo-dpb.gc.ca/files/files/PreBudgetOutlook 2015.pdf>.

42. Roberge, above n. 36, at 133-4.

43. See e.g. M.G. Cohen, J. Stanford \& S. Gindin, 'A Canadian Dimension Roundtable on the Global Economic Crisis', 46(1) Canadian Dimension 12 (2012); G. Isfeld, 'OECD Slashes Canada's Economic Forecast for 2015, but Gives Hope of Growth to Come', National Post, 3 June 2015, available at: <http://business.financialpost.com/news/economy/cana das-economy-to-restart-growth-for-the-rest-of-2015-reports>;

G. Isfeld, 'As IMF Sounds Alarm on Canadian Economy, Policymakers Told to Keep Supporting Growth', National Post, 16 April 2013, available at: <http://business.financialpost.com/news/economy/imf-canadaeconomy>. 
in near-term infrastructure and public sector spending. ${ }^{44}$ Many people are of the view that the former government's 'cutback process' was very much 'mired in secrecy', ${ }^{45}$ and the ongoing impact of many former cuts cannot be determined at this time. ${ }^{46}$ Some of the funding cuts related to justice programme grants and contributions and a cut of roughly $20 \%$ of the Department of Justice's research funding. ${ }^{47}$ Ultimately, the former government's response to the crisis was uneven. Although early indications regarding an increased federal focus on and support for some areas of justice services and research are very positive, it is too early to tell how the new government will approach all of these issues. ${ }^{48}$ Without further empirical study, which is not the purpose of this article, we are not in a position to comment more broadly on the impact of austerity measures to Canadian civil justice.

Whether tied to austerity measures or not, courts continue to identify concerns regarding the state of civil justice in the country. ${ }^{49}$ In Trial Lamyers Association of British Columbia v. British Columbia (Attorney General), ${ }^{50}$ a majority of the Supreme Court struck down regulations that imposed additional costs on litigants. In British Columbia, litigants were charged $\$ 500$ for trials lasting 4-10 days, and a further $\$ 800$ for each additional trial day beyond 10 days. ${ }^{51}$ These fees were premised on two rationales: 'to provide an incentive for efficient use of court time ... [and] to provide sufficient revenue to offset the costs of providing civil justice' in the province. ${ }^{52}$ Although these fees were in place since 1998, the

44. For the Liberal government's basic economic platform, which is currently being fully implemented after the recent election, see e.g. Liberal Party of Canada, Real Change: A New Plan for a Strong Middle Class (Ottawa: Liberal Party of Canada) (2015), at 12, available at: <https:// www.liberal.ca/files/2015/10/A-new-plan-for-a-strong-middle-classBW-1.pdf>

45. Roberge, above n. 36, at 133.

46. L. Whittington, 'Without a Safety Net: Canadians Still in Dark about Budget Cuts, Says Parliamentary Watchdog', Toronto Star, 10 December 2013, available at: <www.thestar.com/news/canada/2013/12/10/ without_a_safety_net_canadians_still_in_dark_about_budget_cuts_says_ parliamentary_watchdog.html>; C. Kenny, 'Harper's Secret Budget Cuts Undermine Canada's Democracy', Huffington Post, 31 January 2015, available at: <www.huffingtonpost.ca/colin-kenny/canada-budgetcuts_b_6249122.html>.

47. See C. Santry, 'Feds Chopping Funding for Some Justice Programs by 20\%', Canadian Lawyer Magazine, 3 April 2013, available at: <www. canadianlawyermag.com/legalfeeds/1397/feds-chopping-funding-forsome-justice-programs-by-20.html>; D. Beeby, 'Justice Canada Chops Research Budget by \$1.2-Million', Globe and Mail, 12 May 2014, available at: <www.theglobeandmail.com/news/politics/justice-canada-cho ps-research-budget-by-12-million/article18598170/>.

48. See Government of Canada, available at: <https://www.canada.ca/en html>; Liberal Party of Canada, available at: <https://www.liberal.ca/>. See further Liberal Party, above n. 44.

49. See e.g. Hryniak, above n. 9; Letang v. Hertz Canada Ltd., 2015 ONSC 72, para. 18, [2015] OJ No 60 (QL); York University v. Michael Markicevic, 2013 ONSC 4311, paras. 2, 14, [2013] OJ No 3014 (QL); Malton v. Attia, 2013 ABQB 642, paras. 191, 90 Alta LR (5th) 1 ('It is a trite observation to say that cost represents a potential bar to Canadian courts and the justice they offer'); Javitz v. BMO Nesbitt Burns Inc et al., 2011 ONSC 1332, paras. 28, 105 OR (3d) 279.

50. 2014 SCC 59 [2014] 3 SCR 31 [Trial Lawyers Association].

51. Ibid., para. 10

52. Ibid., para. 51.
British Columbia government increased these fees in $2010 .^{53}$

The Supreme Court held that, despite exemptions for 'indigent' and 'impoverished' people, these fees unconstitutionally restricted access to Section 96 Superior Courts. The Court affirmed that provincial governments have legislative authority to impose hearing fees, but that this power is not unbounded. ${ }^{54}$ The Court concluded that there must be 'enough judicial discretion to waive hearing fees in any case where [the fees] would effectively prevent access to the courts ... ${ }^{55}$ In this case, the hearing fees prevented a middle-class family from accessing the courts and did 'not promote efficient use of court time; at best [the fee] promote[d] less use of court time'. ${ }^{56}$

This case is particularly relevant to Canada's access to justice challenges and the potential government austerity measures that impact the justice system. While only British Columbia, Yukon, and the Northwest Territories have incremental court hearing fees, other provinces levy fees for court time. ${ }^{57}$ The Supreme Court has clearly signalled to provincial governments that legislation limiting public access to courts must be reasonable and flexible. As provinces may look for ways to recoup the costs of administering justice, the Supreme Court's ruling in Trial Lamyers Association cautions governments from adopting measures that may 'effectively den[y] people the right to take their cases to court' ${ }^{58}$

\subsection{Overarching Principles of Canadian Civil Justice}

Before detailing some of the specific programmes and simplified procedures across Canada, it is important to discuss essential principles that are infused in all Canadian procedural laws: efficiency and proportionality. In Ontario, for example, the Rules of Civil Procedure must 'be liberally construed to secure the just, most expeditious and least expensive determination of every civil proceeding on its merits'. ${ }^{59}$ The Ontario Rules also require that 'the court shall make orders and give directions that are proportionate to the importance and complexity of the issues, and to the amount involved, in the proceeding'. ${ }^{60}$ Most provinces in Canada have rules similar to these that promote efficiency and proportion-

53. Ibid., para. 9

54. Ibid., paras. 18-23, 43.

55. Ibid., para. 48

56. Ibid., para. 63.

57. Vilardell v. Dunham (2012), BCSC 748, para. 95, [2012] BCJ No 1016 (QL). See e.g. Trial Lawyer's Association, above n. 50 (Factum of the Intervener, Attorney General of Alberta, paras. 18-22; Factum of the Intervener, Attorney General of Ontario, paras. 9-13). See also J. Middlemiss, 'Court Fees Face SCC Scrutiny', Canadian Lawyer Magazine, 3 March 2014, available at: <www.canadianlawyermag.com/5034/Court -fees-face-SCC-scrutiny.html>.

58. Trial Lawyers Association, above n. 50, para. 40

59. Rules of Civil Procedure, RRO 1990, Reg 194, r 1.04 (1) [Ontario Rules].

60. Ibid., r 1.04(1.1). 
ality. ${ }^{61}$ In the absence of such rules, provincial courts have readily adopted these concepts. ${ }^{62}$

Efficiency aims to 'improve timeliness and affordability in the civil justice system'. ${ }^{63}$ Proportionality, on the other hand, is a normative concept - while it is difficult to define, ${ }^{64}$ proportionality requires litigants, at a minimum, to evaluate a claim and act in accordance with the importance, complexity, and value of the case. ${ }^{65}$ In $\mathrm{Hry}^{-}$ niak v. Mauldin, the Supreme Court addressed the need for a 'culture shift' in civil litigation that 'entails simplifying pre-trial procedures and moving the emphasis away from the conventional trial in favour of proportional procedures tailored to the needs of the particular case'. ${ }^{66}$ While the Canadian civil justice system is 'premised upon the value that the process of adjudication must be fair and just ... [t]he proportionality principle means that the best forum for resolving a dispute is not always that with the most painstaking procedure'. ${ }^{67}$ Proportionality has taken hold in many other countries, ${ }^{68}$ and the Supreme Court's recent emphasis on this principle has the potential to impact the entire litigation process. In just over a year, lower courts have cited Hryniak and proportionality in the following divergent contexts: whether to hear a matter under simplified rules of procedure, ${ }^{69}$ whether to order the exchange of affidavits prior to a summary judgement motion in the context of a class action; ${ }^{70}$ whether to terminate child support; ${ }^{71}$ whether to order the review and production of sound recordings in a competition case, 72 in fixing the amount of costs ordered; ${ }^{73}$ and in a will

61. Both principles of proportionality and efficiency have been codified in Ontario, British Columbia, Québec, New Brunswick, Manitoba, and Saskatchewan. See Ibid., rr 1.04(1), 1.04(1.1) (Ontario); Supreme Court Civil Rules, BC Reg 168/2009, r 1-3(2) [British Columbia Rules]; Code of Civil Procedure, Arts. 2, 4.2 (Québec); Rules of Court, NB Reg 82-73, rr 1.02.1, 1.03(2) [New Brunswick Rules]; Court of Queen's Bench Rules, Man Reg 553/88, rr 1.04(1), 20A(5) [Manitoba Rules] (Manitoba has only recognised proportionality explicitly in the context of expedited actions); Saskatchewan, The Queen's Bench Rules, r 1-3 [Saskatchewan Rules].

62. Judicial interpretations of civil procedure rules have imported concepts of proportionality in Alberta, Nova Scotia, Newfoundland and Labrador, and Prince Edward Island. See Medicine Shoppe Canada Inc. v. Devchand (2012), ABQB 375, 541 AR 312, para. 11; Saturley v. CIBC World Markets Inc (2011), NSSC 4, 297 NSR (2d) 371, para. 12; Szeto v. Dwyer (2010), NLCA 36, 297 Nfld \& PEIR 311, paras. 53-55; O'Halloran v. Watterson et.ors, 2015 PESC 3, para. 13, 30 MPLR (5th) 1.

63. T.C.W. Farrow, 'Proportionality: A Cultural Revolution', 1 Journal of Civil Litigation and Practice 151, at 153 (2012).

64. D.E. Short and R.A. Gold, 'Proportionality in Theory and Practice', in T.L. Archibald and R.S. Echlin (eds.), Annual Review of Civil Litigation: 2014 (Toronto: Carswell) (2014), 373 at 386.

65. Farrow, above n. 63, at 153-4

66. Hryniak, above n. 9, para. 2.

67. Ibid., paras. 23, 28.

68. Farrow, above n. 63, at 152; J. Walker and L. Sossin, Civil Litigation (Toronto: Irwin Law) (2010), at 247-9.

69. Rochelle et al. v. The Rural Municipality of St Clements et al., 2014 MBCA 102, 310 Man R (2d) 202

70. Fehr v. Sun Life Assurance Co of Canada (2014), ONSC 2183, 240 ACWS (3d) 324.

71. Tarlton v. Jackson, 2014 NSSC 231, 346 NSR (2d) 64.

72. The Commissioner of Competition v. Reliance Comfort Limited Partnership, 2014 CACT 9 [2014] CCTD No 9 (QL).

73. Pinto v. Kaur et al., 2015 ONSC 1356 [2015] OJ No 969 (QL). challenge proceeding. ${ }^{74}$ Proportionality infuses the simplified procedures discussed below, and courts will remain vigilant to ensure that this principle is respected.

\section{Simplified and Summary Procedures in Canada}

Given the Supreme Court's emphasis on a culture shift in civil litigation, there is a growing recognition of the importance of simplified procedures. In fact, the Action Committee listed 'simplify, make coherent, proportional and sustainable' as one of its guiding principles for change in Canadian civil justice. ${ }^{75}$ In this section, we outline some of the simplified and summary procedures found across the country.

\subsection{Simplified Procedures and Fast Track Litigation}

The implementation of 'simplified' or 'expedited' procedures across several jurisdictions has reduced the cost and length of a tradition civil trial. Simplified procedures are a specific set of less complex, and expedited rules that automatically apply to actions for less than a certain monetary amount. ${ }^{76}$ In British Columbia, the simplified procedure is known as 'Fast Track Litigation', and these British Columbia procedures also apply when the trial of an action can be completed in 3 days. ${ }^{77}$ Former Chief Justice of Ontario Warren Winkler described the simplified procedures in Ontario as 'perhaps the most successful recent innovation in our traditional court system' ${ }^{78}$ Even prior to the 2010 expansion of the monetary threshold for the simplified rules in Ontario, over $60 \%$ of civil suits proceeded under the simplified rules. ${ }^{79}$

There are nuances to each provincial simplified procedure regime, and it is not our goal to detail the specifics of each. Generally, however, the provincial schemes

74. Re Estate of Ireni Traitses, deceased, 2014 ONSC 2102, 239 ACWS (3d) 543 .

75. Action Committee on Access to Justice in Civil and Family Matters, above n. 8, at 6, 8 .

76. Each jurisdiction has different monetary thresholds. In Ontario, British Columbia, Manitoba, Saskatchewan, and Nova Scotia, actions for $\$ 100,000$ or less fall under the simplified rules. See Ontario Rules, above n. 59, r 76.02; British Columbia Rules, above n. 61, Part 15; Manitoba Rules, above n. 61, r 20A(2); Saskatchewan Rules, above n. 61, r 8-2(1); Nova Scotia, Nova Scotia Civil Procedure Rules, rr 57-58 [Nova Scotia Rules]. In New Brunswick, simplified procedures apply to claims for $\$ 75,000$ or less. See New Brunswick Rules, above n. 61, r 79.05. The two lowest monetary thresholds for the application of simplified procedures are in Prince Edward Island ( $\$ 25,000$ or less) and Newfoundland and Labrador (\$15,000 or less). See P.E. Island, Annotated Rules of Civil Procedure, r 75.1 [Prince Edward Island Rules]; Newfoundland and Labrador, Rules of the Supreme Court, r 17A.09 [Newfoundland Rules]. In Québec, the 'Court of Québec has jurisdiction to the exclusion of the Superior Court' in matters where less than $\$ 70,000$ is claimed. See Code of Civil Procedure, Art. 34

77. British Columbia Rules, above n. 61, r 15-1(1)(b)

78. Honourable W.K. Winkler, 'The Vanishing Trial', 27(2) Advocates' Society Journal 3 (2008), para. 18 (QL).

79. Honourable W.K. Winkler, 'Professionalism and Proportionality', 27(4) Advocates' Society Journal 6, at 6 (2009). 
share several common characteristics. First, most simplified procedures limit the amount of time available for examinations for discovery. ${ }^{80}$ Civil trials often get delayed as a result of protracted examinations of witnesses. Therefore, these rules prevent costly examinations and constrain discovery so that the purpose remains 'to learn and discover the opposing party's position on the key issue in dispute'. ${ }^{81}$ For example, in Manitoba, no party may conduct an examination for discovery under the expedited rules on an action worth less than $\$ 50,000$ without leave of a judge. ${ }^{82}$ Further, on an action under the expedited procedure that is worth $\$ 50,000$ or more, examinations for discovery cannot exceed 3 hours. ${ }^{83}$

Second, several of the simplified procedure regimes require parties to attend pre-trial or case planning conferences. ${ }^{84}$ These case management measures ensure that matters are scheduled efficiently and that the issues in dispute are focused. In Ontario, the rules mandate a pre-trial conference at least 45 days before the scheduled trial date. ${ }^{85}$ In British Columbia, a case planning conference must be completed before a party can serve a notice of application or an affidavit supporting the application on another party to the action. ${ }^{86}$

Third, special fixed costs rules are often associated with simplified procedures. ${ }^{87}$ These specified costs incentivise the parties to complete the action on time to keep costs low and predictable. An example of a fixed costs system is found in Saskatchewan. The Saskatchewan Queen's Bench Rules of Court provide that a successful party under the expedited procedures is entitled to fixed costs if the hearing of the trial is less than 3 days. ${ }^{88}$ In fact, in New Brunswick, for example, the rules impose additional cost consequences on a party that improperly fails to use the simplified procedures. ${ }^{89}$

While the simplified procedural schemes are a significant step towards reducing the complexity and cost of civil proceedings, some have critiqued the way these

80. See e.g. Ontario Rules, above n. 59, r 76.04; British Columbia Rules, above n. 61, r 15-1(11); Saskatchewan Rules, above n. 61, r 8-7; Manitoba Rules, above n. 61, rr 20A(39)-(41); Nova Scotia Rules, above n. 76, r 57.10. In fact, in New Brunswick and Prince Edward Island, discovery is not allowed in a simplified action, unless otherwise permitted by the court. See New Brunswick Rules, above n. 61, r 79.07; Prince Edward Island Rules, above n. 76, r 75.1.04

81. N. Champion, 'Litigation Simplified: The New Rule 76', Paper Delivered at 'Your First Civil Trial' Conference, Ontario Bar Association Continuing Professional Development, Toronto, Ontario, 8 March 2013, at 7 (unpublished) (emphasis in original).

82. Manitoba Rules, above n. 61, r 20A(40).

83. Ibid., $\mathrm{r} 20 \mathrm{~A}(41)$. Of course, the case management judge has discretion under the rules to extend an examination for discovery where it is appropriate. See Ibid., r 20(A)(41)(b).

84. See e.g. British Columbia Rules, above n. 61, r 15-1(7); Saskatchewan Rules, above n. 61, r 8-8; Manitoba Rules, above n. 61, 20A(9); Prince Edward Island Rules, above n. 76, r 75.1.09; Ontario Rules, above $\mathrm{n}$ 59, $r$ 76.10(1).

85. Ibid.

86. British Columbia Rules, above n. 61, r 15-1(7).

87. See e.g. Ibid., r 15-1(15); New Brunswick Rules, above n. 61, r 79.11 (which limits the scale of costs that can be awarded in an action under the simplified rules); Saskatchewan Rules, above n. 61, r 8-11.

88. Ibid.

89. New Brunswick Rules, above n. 61, r 79.12 procedures categorise cases. Janet Walker and Lorne Sossin write that:

drawing bright procedural lines based solely on the damages claimed in civil litigation turns a private calculation (how individuals quantify harm or loss) into a public calculation (how the civil justice system allocates rights to discovery and cross-examination), without reference to other indicia of the public interest. $^{90}$

Alberta's recently enacted rules of civil procedure acknowledge this critique and the limited utility of damages claimed as a sorting mechanism. Rather than sorting cases by the amount claimed, Alberta cases must be categorised as either 'standard' or 'complex'.91 This classification is made on the basis of a number of factors, including the amount claimed, the complexity of the issues, the number of parties, and the importance of the issues. $^{92}$ Proportionate procedures apply to each type of action.

\subsection{Summary Judgement and Special Cases} Simplified procedures apply to the conduct of the entire litigation process, but there are several ways to resolve a dispute before it proceeds too far through this process. A summary judgement motion is one of these mechanisms. On a summary judgement motion, the motion judge can resolve the claim by looking at the merits of the action disclosed in the pleadings, affidavits, and cross-examined affidavits tendered by the parties. ${ }^{93}$ The action is typically disposed of on a 'paper record' rather than through viva voce evidence. ${ }^{94}$ It is an important tool for enhancing access to justice because it can provide a cheaper, faster alternative to a full trial'. ${ }^{95}$ Every province, other than Québec, has a summary judgement procedure. $^{96}$

The question remains: when is summary judgement available? In Hryniak v. Mauldin, the Supreme Court set out the governing framework. This case was decided in the context of the Ontario rules, although the Court was clear that 'the values and principles underlying its interpretation are of general application'. ${ }^{97}$ In Ontario, Rule 20.04 states that the court shall grant summary judgement if "the court is satisfied that there is no genu-

90. Walker and Sossin, above n. 68 , at 221

91. Alberta Rules of Court, Alta Reg 124/2010, r 4.3 [Alberta Rules].

92. Ibid., r 4.3(2)

93. Walker and Sossin, above n. 68 , at 210. As we explain, the summary judgement procedure in British Columbia is more limited than the procedure in Ontario. See text accompanying n. 90-93.

94. Walker and Sossin, above n. 68 , at 210. However, in some jurisdictions, viva voce evidence may be allowed on a motion for summary judgement. See e.g. Ontario Rules, above n. 59, r 20.04 (2.2); Hryniak, above n. 9, paras. 61-65.

95. Ibid., para. 34.

96. See e.g. Ontario Rules, above n. 59, r 20; Manitoba Rules, above n. 61, r 20; Prince Edward Island Rules, above n. 76, r 20. Québec has a procedure that is similar to summary judgement, although it is not as broad as the summary judgement rules in other provinces. See Code of Civil Procedure, Arts. 54.1-54.3, 165(4); Hryniak, above n. 9, para. 34, n. 4.

97. Hryniak, above n. 9, para. 35. 
ine issue requiring a trial' ${ }^{98}$ The Supreme Court held that there will be no issue requiring a trial when:

the [summary judgment] process (1) allows the judge to make the necessary findings of fact, (2) allows the judge to apply the law to the facts, and (3) is a proportionate, more expeditious and less expensive means to achieve a just result. ${ }^{99}$

In Ontario, a motion judge can also weigh evidence, evaluate the credibility of a deponent, and draw reasonable inferences from the evidence 'unless it is in the interest of justice for such powers to be exercised only at a trial'. ${ }^{100}$ On this question, the Supreme Court held that '[i]n practice, whether it is against the "interest of justice" to use [these powers] will often coincide with whether there is a "genuine issue requiring a trial". Additionally, 'these powers are presumptively available, rather than exceptional, in line with the goal of proportionate, cost-effective and timely dispute resolution'. ${ }^{101}$

Hryniak challenges the primacy of the conventional trial for resolving civil disputes by elevating the need for the most proportionate, not 'most painstaking procedure' ${ }^{102}$ Many legal observers wondered how the Canadian legal community would respond to Hryniak and we do not attempt to outline the subsequent case law in this article. However, one litigator concluded on her preliminary review of Ontario cases that 'summary judgment motion judges appear to have taken Hryniak to heart'. ${ }^{103}$ Jonathan Lisus, a senior trial lawyer, writes that Hryniak 'seems to have touched a nerve in positive and unexpected ways' ${ }^{104}$ In his view, Hryniak invites trial counsel to persuade judges to allow cost-conscious, reasonably conducted trials such as 'directed trials of issues, hybrid trials with evidence in chief by affidavit, stop-clock trials and bifurcated proceedings'. ${ }^{105}$ As the lessons from Hryniak continue to percolate across the country, there is hope that this decision will contribute to the simplification and increased affordability of civil justice.

It is worth noting that the summary judgement procedure in Ontario is different than the procedure found in British Columbia, potentially calling into question the direct procedural applicability of Hryniak in British Columbia (although, of course, the underlying princi-

98. Ontario Rules, above n. 59, r 20.04 (2)(a). Summary judgement can also be granted if the parties agree to it, and the court is satisfied that summary judgement is appropriate in the circumstances.

99. Hryniak, above n. 9, para. 49.

100. Ontario Rules, above n. 59, r 20.04 (2.1).

101. Hryniak, above n. 9, para. 67.

102. Ibid., paras. 1, 27-28.

103. S. Chaudhury, 'Hryniak v. Mauldin: Has the Supreme Court Finally Provided Us with Clear Guidance on Summary Judgment?', Paper Delivered at the Twelve-Minute Civil Litigator Conference, Law Society of Upper Canada Continuing Professional Development, 18 September 2014, at 5 (unpublished).

104. J. Lisus, 'Hryniak: Requiem for the Vanishing Trial, or Brave New World', 33(1) Advocates' Society Journal 6 (2014), para. 12 (QL).

105. Ibid., para. 29. ples will apply). ${ }^{106}$ In Ontario, motion judges have the power to weigh evidence ${ }^{107}$ and the discretion to allow oral evidence. ${ }^{108}$ In contrast, motion judges can only decide whether there is a genuine issue for trial in British Columbia. As we discuss below, the limited scope of the British Columbia summary judgement rule has led to the primacy of the summary trial procedure in that province. ${ }^{109}$

In addition, on issues of law alone, all jurisdictions in Canada have a procedure for the expedient determination of a legal question. ${ }^{110}$ This procedure is known as a 'special case' or a 'stated case'. For example, in New Brunswick, a court may grant leave to hear a special case on consent of the parties and with an agreed upon statement of facts. ${ }^{111}$ A special case is typically only appropriate where the determination of the special case will dispose of the underlying matter or advance the proceedings. $^{112}$

\subsection{Summary Trials}

A procedural innovation that is somewhat similar to summary judgement and simplified procedures is a summary trial. While these concepts overlap, they are each distinct. Simplified procedures govern the entirety of the litigation process, whereas summary judgement and summary trials are ways to resolve the dispute. An Alberta Court of Appeal decision recently explained the difference between these two dispute resolution mechanisms:

Summary judgment disposes of a suit before trial and summary trial after trial. Summary judgment removes from the litigation stream those disputes in which the [nonmoving party's] position is without merit. If the moving party's position is unassailable, it makes sense to allocate as few public and private resources as possible to resolve a dispute the outcome of which is obvious .... The summary trial mechanism is designed to resolve disputes which display features amenable to just resolution without accessing all aspects of the trial protocol. Proceedings which do

106. Century Services Inc. v. LeRoy, 2014 BCSC 702, paras. 83-87, [2014] BCJ No 725 rev'd on other grounds, 2015 BCCA 120, [2015] BCJ No 499 (QL). There is also some suggestion that Hryniak is not directly applicable to the rules in Alberta. See text accompanying note 106, below. The summary judgement rules in Saskatchewan are similar to those in Ontario. SeeSaskatchewan Rules, above n. 61, r 7-5; Pervez v. Caskey, 2013 SKQB 377, paras. 39, 431 Sask R 201.

107. Ontario Rules, above n. 59, r 20.04 (2.1).

108. Ibid., r 20.04 (2.2)

109. The British Columbia summary trial procedure is used in a majority of cases in the province. See Honourable C.A. Osborne, Civil Justice Reform Project: Summary of Findings \& Recommendations (Toronto: Queen's Printer for Ontario) (2007), at 38-9, available at: <www. attorneygeneral.jus.gov.on.ca/english/about/pubs/cjrp/CJRP-Report_ EN.pdf>.

110. Walker and Sossin, above n. 68, at 221. See e.g. Ontario Rules, above n. 59, r 22; British Columbia Rules, above n. 61, rr 9-3, 9-4; Newfoundland Rules, above n. 76, r 37; New Brunswick Rules, above n. 61, r 24.01 (called a 'stated case').

111. Ibid., rr 24.01, 24.02, 24.04.

112. Ibid., r 24.01. See also Ontario Rules, above n. 59, r 22.01(2). 
not involve contested facts or complicated legal issues are well suited for summary trial. But it is still a trial. ${ }^{113}$

The summary trial was first developed in 1983 in British Columbia as a response to the shortcomings of British Columbia's summary judgement rule. Summary judgement motions had caused dissatisfaction in the province. Under the British Columbia rules, summary judgement could only be granted in cases where there was no reasonable defence to a claim. Thus, 'artful pleaders' could raise an argument that would defeat a summary judgement motion. ${ }^{114}$ The summary trial procedure was the legislature's response to these challenges. Under the British Columbia rules, summary trials are conducted through affidavit evidence, and the evidence can include an expert report or part of an examination for discovery. ${ }^{115}$ The judge has broad discretion to order cross-examinations on affidavits. ${ }^{116}$ Judgement may be granted in favour of either party unless 'the court is unable ... to find the facts necessary to decide the issues of fact or law' or 'the court is of the opinion that it would be unjust to decide the issues on the application'. ${ }^{117}$ A summary trial in British Columbia, unlike summary judgement in that province, can be used to merely decide 'an issue' in dispute. ${ }^{118}$

Other provinces have followed British Columbia's lead and implemented summary trial procedures. ${ }^{119}$ For example, Alberta adopted a summary trial procedure similar to that of British Columbia. ${ }^{120}$ However, unlike in British Columbia, oral evidence is permitted during a summary trial in Alberta with the permission of the judge. ${ }^{121}$ Alberta's summary judgement procedure is similar to British Columbia's procedure, but it also shares features with the more comprehensive Ontario procedure. As the Alberta courts develop the summary judgement procedure in light of Hyrniak, it remains to be seen whether summary judgement will overtake the role of summary trials in Alberta. ${ }^{122}$

In Ontario, summary trials are available in a more limited context. In a case under the simplified rules, parties may opt to have a summary trial rather than an ordinary

113. Can v. Calgary Police Service, 2014 ABCA 322, paras. 87-88, 315 CCC (3d) 337 (citations omitted).

114. Inspiration Management Ltd v. McDermid St Lawrence Ltd (1989), 36 BCLR (2d) 202, [1989] BCJ No 1003 (QL), paras. 37-38 (CA) [cited to $\mathrm{QL}$. However, the British Columbia summary judgement rules are different that the rules in Ontario. See above text accompanying $n$. 106-109.

115. British Columbia Rules, above n. 61, r 9-7(5).

116. Ibid., r 9-7(12).

117. Ibid., r 9-7(15).

118. Century Services Inc. v. LeRoy, 2015 BCCA 120, paras. 38-49, [2015] BCJ No 499 (QL).

119. See e.g. Manitoba Rules, above n. 61, r 20.06; Ontario Rules, above n. 59, r 76.12 (1); Alberta Rules, above n. 91, rr 7.5-7.11. See also Nova Scotia Rules, above n. 76, r 57.11 (which requires an 'economic trial' for actions claiming under $\$ 100,000)$.

120. Alberta Rules, above n. 91, rr 7.5-7.11.

121. Ibid., rr 6.11(1)(g), 7.7(2).

122. See Windsor v. Canadian Pacific Railway, 2014 ABCA 108, 371 DLR (4th) 339. But see Can v. Calgary Police Service, 2014 ABCA 322, paras. 97-104, 116 WCB (2d) 578. trial. ${ }^{123}$ Under the summary trial procedure in Ontario, evidence is adduced by affidavit, but the plaintiff and defendant have the opportunity to examine and crossexamine the deponents for a short period of time. ${ }^{124}$ Furthermore, oral argument is permitted after the presentation of the evidence. ${ }^{125}$

Summary trials have been very popular in British Columbia given the limits of the province's summary judgement procedure. ${ }^{126}$ Even in provinces such as Ontario, where the summary judgement procedure is flexible and robust, summary trials are a useful tool to simplify and expedite the dispute resolution process.

\subsection{Small Claims Courts}

Small claims courts have a long history in Canada. Originating from the early debt collection courts, these courts have been re-imagined through legislative reforms and are now commonplace across the country. ${ }^{127}$ They have been very popular with litigants; for example, 66,059 claims were filed in Ontario Small Claims Court in 2012-2013, representing 45\% of all civil cases commenced in the province that year. ${ }^{128}$ One commentator lists the following as the goals and hallmarks of small claims courts: informality, ease, speed, affordability, fairness, and resolves small disputes. ${ }^{129}$ While a 'uniform mandate [for small claims courts] across the country remains illusory' ${ }^{130}$ common features exist in the courts in each province. ${ }^{131}$

Eligibility to pursue an action in small claims court is governed by the monetary value of the claim. As these courts are premised on efficiency and simplicity, monetary limits impact the types of litigants that can access these informal courts. In most provinces, small claims courts have jurisdiction over cases valued at $\$ 25,000$ and

123. Ontario Rules, above n. 59, r 76.10(6).

124. Ibid., r 76.12 (1)

125. Ibid.

126. Osborne, above n. 109, at 38-9.

127. S. McGill, 'Small Claims Court Identity Crisis: A Review of Recent Reform Measures', 49 Canadian Business Law Journal 213, at 214 (2010); I. Ramsay, 'Small Claims Courts: A Review' in Rethinking Civil Justice: Research Studies for the Civil Justice Review (Toronto: Ontario Law Reform Commission) (1996) 489, at 492.

128. Ministry of the Attorney General, Court Services Division: Annual Report 2012-2013 (Toronto: Queen's Printer for Ontario) (2013), at 36, available at: <www.attorneygeneral.jus.gov.on.ca/english/about/ pubs/courts_annual_12/Court_Services_Annual_Report_FULL_EN.pdf>. For information in the British Columbia courts, see Provincial Court of British Columbia, Annual Report 2013-2014 (2014), at 14, available at: $<$ www.provincialcourt.bc.ca/downloads/pdf/AnnualReport2013-2014. pdf>.

129. McGill, above n. 127 , at 217-8.

130. Ibid., at 249.

131. Many studies have discussed small claims in Canada at length. See e.g. Ramsay, above n. 127; McGill, above n. 127; S.C. McGuire and R.A. MacDonald, 'Small Claims Court Cant', 34(3) Osgoode Hall Law Journal 509 (1996); M.W. Patry, V. Stinson \& S.M. Smith, Evaluation of the Nova Scotia Small Claims Court: Final Report to the Nova Scotia Law Reform Commission (Halifax: Saint Mary's University) (2009), available at: <www.lawreform.ns.ca/Downloads/SmallClaimsFinaReportFINAL. $\mathrm{pdf}>$ 
under. ${ }^{132}$ Québec has a lower limit, as its small claims court will currently only hear matter valued at $\$ 15,000$ or less. ${ }^{133}$ In contrast, Alberta recently raised the upper limit of the monetary jurisdiction of its small claims courts from $\$ 25,000$ to $\$ 50,000 .{ }^{134}$ This reform must be viewed in the context of Alberta's 'simple' and 'complex' categorisation of claims, as discussed above. The mixed methodologies of classifying claims in Alberta may give litigants increased choice for court-based dispute resolution.

Provinces also have different approaches to who can access small claims courts and the types of claims that these courts can hear. Some small claims courts were designed as a 'people's court', and therefore, these courts restrict the access of certain corporate actors. ${ }^{135}$ For example, in Québec and Nova Scotia, business creditors only have limited access to small claims courts. $^{136}$ In other provinces, these concerns are not manifest. In Ontario, a large portion of the small claims docket is debt collection. ${ }^{137}$ In fact, British Columbia started a pilot project for a specific debt collection procedure in small claims courts. ${ }^{138}$

The cost of small claims is also an important indicator of whether these courts are making the justice system more affordable. One indicia of cost is the necessity of representation in small matters. ${ }^{139}$ In Québec, lawyers are forbidden from representing litigants in small claims courts, absent exceptional circumstances. ${ }^{140}$ Yet, lawyers are permitted in many provinces. ${ }^{141}$ Some have argued that lawyers should not be permitted in small

132. This is the highest value Small Claims Courts will hear in Ontario, British Columbia, Nova Scotia, Newfoundland and Labrador, and the Yukon. See Small Claims Court Jurisdiction and Appeal Limit, O Reg 626/00, s 1 (Ontario); Small Claims Rules, BC Reg 261/93, r 1(4) [BC Small Claims Rules]; Small Claims Court Forms and Procedures Regulations, NS Reg 17/93, s 2(b) (Nova Scotia); Small Claims Rules, NL Reg 52/97, r 3(4) [Newfoundland Small Claims Rules]; Small Claims Court Regulations, YOIC 1995/152, Sched A, cl 1 (Yukon). See also S. Mireau, 'Small Claims', SLAW, 15 July 2014, available at: <www.slaw.ca/2014/ 07/15/small-claims/>

133. Code of Civil Procedure, Art. 953.

134. 'Higher Small Claims Court Limit Increases Access to Justice', 21 July 2014, available at: <http://alberta.ca/release.cfm?xID=36856F648A53F -BA5B-A6D3-942144FBE5372212>. See Provincial Court Civil Division Regulation, AR 329/89, s 1.1. The small claims court in Alberta is known as the Civil Division of the Provincial Court of Alberta.

135. See McGuire and MacDonald, above n. 131, at 531.

136. Code of Civil Procedure, Art. 953 (Québec); Small Claims Court Act, RSNS 1989, c 430, s 5 [Nova Scotia Small Claims Act]. McGuire and MacDonald note that, despite these restrictions, the Montréal Small Claims court they studied was 'heavily populated' by debt collection claims pursued by 'professionals and self-employed businesspersons'. See McGuire and MacDonald, above n. 131, at 531.

137. L.M. Olivo and D.M.P. Gonsalves, Small Claims Court Practice and Procedure in Ontario (Concord, ON: Captus Press) (2013), at 136. See also Patry, Stinson \& Smith, above n. 131, at 9-10.

138. BC Small Claims Rules, above n. 132, r 9.2. See also Ministry of Justice, 'Provincial Small Claims Court Pilot', 16 January 2014, available at: <www.ag.gov.bc.ca/courts/small_claims/info/pilot.htm>

139. It is beyond the scope of this article to discuss small claims court fees, but these are also important costs that impact the cost of small claims. For a discussion of this issue, see McGill, above n. 127, at 231-4.

140. Code of Civil Procedure, Art. 959.

141. See e.g. Nova Scotia Small Claims Act, above n. 136, s 16; BC Small Claims Rules, above n. 132, r 17(20); Small Claims Act, 1997, SS 1997, c S-50.11, s 29 [Saskatchewan Small Claims Act]. claims courts, as they increase costs and power imbalances between litigants. ${ }^{142}$ Provinces such as Saskatchewan and Manitoba allow lawyers but discourage their use by limiting the costs awards available for legal fees. ${ }^{143}$ In Ontario, lawyers and other legal actors such as paralegals and law students are permitted to represent individuals in small claims court. ${ }^{144}$ Perhaps, Ontario's approach of allowing a broader range of representatives provides more flexibility and affordability to those who do seek representation.

Post-recession austerity did impact small claims in one jurisdiction in Canada. In 2009, the New Brunswick government announced that it would abolish its small claims court and transfer all claims to the trial court. ${ }^{145}$ The government justified its decision as a cost-saving measure given the financial difficulties facing the province. ${ }^{146}$ The Canadian Bar Association opposed this move $^{147}$ and the Chief Justice of the New Brunswick Court of Queen's Bench called the decision 'regressive'. ${ }^{148}$ During the next provincial election, the opposition campaigned on a promise to reinstate the small claims court. After winning the election, the new government followed through and reintroduced the court. ${ }^{149}$ As this chapter in Canadian provincial politics demonstrates, small claims courts are an important aspect of Canadian civil justice, irrespective of funding difficulties.

An exciting technological innovation in British Columbia may spark a new way to resolve small claims in the future. In 2012, the British Columbia government passed the Civil Resolution Tribunal Act, introducing

142. Patry, Stinson \& Smith, above n. 131, at 17-9

143. McGill, above n. 127, at 230-31. See e.g. Newfoundland Small Claims Rules, above n. 132, r 24(2) (in Newfoundland, costs are capped at $10 \%$ of the claim); Saskatchewan Small Claims Act, above n. 141, s 31 (no lawyer-related costs can be granted); The Court of Queen's Bench Small Claims Practices Act, RSM 1987, c C285 (CCSM c C285), s 14(1) (in Manitoba, costs are capped at \$100).

144. Courts of Justice Act, RSO 1990, c C.43, s 26 ('A party may be represented in a proceeding in the Small Claims Court by a person authorized under the Law Society Act to represent the party'). A Law Society bylaw provides that paralegals, law students, and various other non-lawyers can represent individuals in Ontario Small Claims Court. See Law Society of Upper Canada, by-law 4, Licensing, ss 5-6, 13, 28-35; Olivo and Gonsalves, above n. 137, at 13-24. Additionally, a pro bono programme in Ontario provides summary advice and assistance to small claims litigants that are eligible. See 'Pro Bono (Free) Legal Assistance', available at: <https://www.lawhelpontario.org/lawsuits-disputes/small claimscourt/howwehelp/>

145. See An Act to Repeal the Small Claims Act, SNB 2009, c 28.

146. McGill, above n. 127, at 242.

147. Canadian Bar Association, News Release, 'CBA-NB Opposes Elimination of Small Claims Court', 16 March 2009, available at: <www.cba.org/ NB/pdf/New\%20Release\%20March\%202009.pdf>.

148. 'Access to Justice Compromised in New Brunswick by Elimination of Small Claims Court', 10 March 2010, available at: <www.ccla.org/ rightswatch/2010/03/10/access-to-justice-compromised-in-newbrunswick-by-elimination-of-small-claims-court/>

149. See Small Claims Act, SNB 2012, c 15. See also CBC News, 'Small Claims Court to be Reinstated', CBC News, 5 April 2012, available at: $<$ www.cbc.ca/news/canada/new-brunswick/small-claims-court-to-bereinstated-1.1186899>; CBC News, 'Small Claims Court Bill Introduced', CBC News, 11 May 2012, available at: <www.cbc.ca/news/ canada/new-brunswick/small-claims-court-bill-introduced-1.1186897>. 
Canada's first online dispute resolution forum. ${ }^{150}$ Although the tribunal is not yet operational, it is expected to launch online this year. ${ }^{151}$ The Chair of the Civil Resolution Tribunal explained that this innovation will provide 24 hours 'access to interactive information pathways, tools, and a variety of dispute resolution methods including negotiation, facilitation and, if necessary, adjudication'. ${ }^{152}$ Parties must represent themselves in most circumstances. ${ }^{153}$ If a matter proceeds through the tribunal to adjudication, a tribunal member will receive submissions and render a binding judgement, delivered via e-mail. ${ }^{154}$ The provincial government introduced a new bill in March 2015 that will require small claims to proceed through the Civil Resolution Tribunal before moving to small claims court. ${ }^{155}$ If this project is successful, it could reshape civil justice for small matters in British Columbia and act as a model for other jurisdictions. ${ }^{156}$

\subsection{Court-Based Alternative Dispute Resolution} While our focus to this point has been on court-based dispute resolution in small and simple matters, our discussion would be incomplete without canvassing the pre-trial alternative dispute resolution (ADR) processes in place across Canada. Like many jurisdictions around the world, Canada has embraced ADR as an effective set of tools for resolving civil and family disputes. Although growing in modern popularity since the 1970s, in 1996, the Canadian Bar Association released an influential report recommending that all jurisdictions 'make available as part of the civil justice system opportunities for litigants to use non-binding dispute-resolution processes as early as possible in the litigation process' ${ }^{157}$ Most jurisdictions in Canada have headed this recommendation. In this section, we outline some of the specific state-based or state-sanctioned pre-trial ADR pro-

150. Civil Resolution Tribunal Act, SBC 2012, c 25. See also Ministry of Justice, 'Civil Resolution Tribunal Act', 10 March 2015, available at: <www. ag.gov.bc.ca/legislation/civil-resolution-tribunal-act/>

151. 'FAQs', available at: <www.civilresolutionbc.ca/faqs/>

152. S. Slater, 'B.C.'s Civil Resolution Tribunal', Paper Delivered at the Osgoode Forum on Administrative Law and Practice, Toronto, Ontario, 23-24 October 2014, available at: <www.civilresolutionbc.ca/b-c-s-civil -resolution-tribunal/>

153. J. Sorensen, 'B.C. Lawyers Worried about Exclusion from New Civil Resolution Tribunal', Canadian Lawyer Magazine, 2 September 2013, available at: <www.canadianlawyermag.com/legalfeeds/1653/bclawyers-worried-about-exclusion-from-new-civil-resolution-tribunal. html>

154. Slater, above n. 152.

155. Bill 19, Civil Resolution Tribunal Amendment Act, 2015, 4th Sess, 40th Parliament, British Columbia, cl 14.1.

156. For other Canadian online dispute resolution initiatives in the context of traffic offences, see M. Erdle, 'Ontario Joins Wider Move toward Online Dispute Resolution to Ease Court Burdens', SLAW, 25 March 2015, available at: <www.slaw.ca/2015/03/25/ontario-joins-wider-movetoward-online-dispute-resolution-to-ease-court-burdens/>.

157. Canadian Bar Association, Systems of Civil Justice: Task Force Report (Ottawa, Canadian Bar Association) (1996), at v, available at: <https:// www.cba.org/cba/pubs/pdf/systemscivil_tfreport.pdf>. For current national calls for continued efforts in this and related areas, see e.g. Action Committee on Access to Justice in Civil and Family Matters, above n. 8 , at 13,22 grammes that have been implemented across the country. ${ }^{158}$

Mediation is a popular early dispute resolution mechanism that is recommended or required in several provinces and in certain small claims courts. ${ }^{159}$ Saskatchewan was one of the first provinces to implement mandatory mediation in civil proceedings. ${ }^{160}$ This reform was implemented to achieve better substantive results for litigants, not to address court backlog in the province. ${ }^{161}$ Mediators in the Saskatchewan programme are generally non-lawyers and are assigned by the government to any civil claim filed in court. ${ }^{162}$ A study of Saskatchewan's mediation programme conducted 10 years after its implementation concluded that, despite several challenges, 'some of [the program's] ambitious goals for cultural and systemic change are being realized. The process of litigation has been altered in some significant ways, for both lawyers and clients'. ${ }^{163}$ Mandatory mediation is also required in actions commenced in three of the major litigation centres in Ontario. ${ }^{164}$ The stated goal of the Ontario programme is to 'reduce cost and delay in litigation and facilitate the early and fair resolution of disputes'. ${ }^{165}$ Unlike in Saskatchewan, parties must privately contract with an approved mediator in Ontario. ${ }^{166}$ Despite this difference, the Ontario programme has also been well received. ${ }^{167}$

Beyond mediation, many provinces require or recommend that parties engage in settlement discussions or a

158. In this article, we focus primarily on formal state-based, as opposed to all public and private, forms of ADR processes. For a recent and much more detailed discussion of state-based, state-sanctioned, and fully private ADR programs, initiatives, and trends in place across the country, see Farrow, Civil Justice, above n. 5, at 89-117.

159. See e.g. Alberta Rules, above n. 91, r 4.16; Alberta Court of Queen's Bench, 'Alberta Justice Mediation Service for the Court of Queen's Bench', available at: <https://albertacourts.ca/court-of-queens-bench/ civil-mediation>; Ontario Rules, above n. 59, r 24.1.04(1); The Queen's Bench Act, 1998, SS 1998, c Q-1.01, s 42 [Saskatchewan Queen's Bench Act]; Saskatchewan Rules, above n. 61, r 4-10; Newfoundland Rules, above n. 76, r 37A. In British Columbia, mediation is not mandatory, but any party to a claim can serve the other parties to the action with a Notice to Mediate. In doing so, any party can compel the others to participate in mediation. See Notice to Mediate (General) Regulation, BC Reg 4/2001. Some small claims courts also incorporate mediation. See McGill, above n. 127 at 237-9; Farrow, Civil Justice, above n. 5 , at 113-6.

160. Saskatchewan Queen's Bench Act, above n. 159, s 42; Saskatchewan Rules, above n. 61, r 4-10.

161. J. MacFarlane and M. Keet, 'Civil Justice Reform and Mandatory Civil Mediation in Saskatchewan: Lessons from a Maturing Program' 42(3) Alberta Law Review 677, at 678-9 (2005).

162. Ibid., at 682,693

163. Ibid., at 681 .

164. Ontario Rules, above n. 59, r 24.1.04(1).

165. Ibid., r 24.1.01

166. MacFarlane and Keet, above n. 161, at 682. Alberta also provides a roster of approved mediators to choose from. See Alberta Court of Queen's Bench, above n. 159. See also Mediation Rules of the Provincial Court - Civil Division, Alta Reg 271/97

167. Farrow, above n. 5, at 106-7 
settlement conference before proceedings to trial. ${ }^{168}$ In British Columbia and Québec, the parties may request a settlement conference where a judge or master 'must, in private and without hearing witnesses, explore all possibilities of settlement of the issues that are outstanding'. ${ }^{169}$ Ontario requires that parties schedule a pre-trial conference after setting down an action for trial to, inter alia, 'provide an opportunity for any or all of the issues in a proceeding to be settled without a hearing'. ${ }^{170}$ In certain provinces, there are also cost consequences if a party fails to accept a favourable settlement offer. ${ }^{171}$ The most recent proposal in this area is from Québec. In its newly proposed civil justice rules, parties 'must consider private prevention and resolution processes before referring their dispute to the courts'. ${ }^{172}$

A specific type of settlement conference is commonplace in two of the Prairie Provinces. Judicial dispute resolution (JDR) is widespread across Alberta, although the province's rules only require good faith participation in one of several ADR process prior to trial. ${ }^{173} \mathrm{JDR}$ is a confidential pre-trial settlement conference that is led by a judge, as opposed to a master, mediator, or adjudicator. ${ }^{174}$ If no agreement is reached during the conference, the judge may give a non-binding opinion as to how he or she would decide the case on the facts. ${ }^{175}$ The Alberta judiciary is largely responsible for JDR, and the evidence of high usage rates and high settlement rates suggests that it has been successful. ${ }^{176}$ Judicially assisted dispute resolution (JADR), a programme similar to

168. See e.g. British Columbia Rules, above n. 61, Part 9; Ontario Rules, above n. 59, r 50; Code of Civil Procedure, Arts. 151.14-151.23 (Québec); Nova Scotia Rules, above n. 76, rr 10.11-10.16; New Brunswick Rules, above n. 61, rr 50.07-50.15; Newfoundland Rules, above n. 76, 18.A.06(3). A settlement conference is even required in every contested small claims matter in Ontario. See Ontario Small Claims Rules, O Reg 258/98, r 13.01.

169. British Columbia Rules, above n. 61, r 9-2(1); Code of Civil Procedure, Art. 151.16 (in Québec's Code of Civil Procedure, very similar language is used).

170. Ontario Rules, above n. 59, rr 50.01, 50.02

171. See e.g. Ontario Rules, above n. 59, r 49.10; British Columbia Rules, above n. 61, r 9-1(4)

172. Bill 28, An Act to Establish the New Code of Civil Procedure, 1st Sess, 40th Leg, Québec, 2015, cl 1 (assented to 21 February 2014). The bill will come into force 1 January 2016. See Y. Saint-Cyr, 'Reminder: New Quebec Code of Civil Procedures Effective January 1, 2016', SLAW, 29 October 2015, available at: <www.slaw.ca/2015/10/29/reminder-newquebec-code-of-civil-procedures-effective-january-1-2016/>; Justice Québec, 'Code of Civil Procedure', 24 February 2014, available at: <www.justice.gouv.qc.ca/english/sujets/glossaire/code-proc-a.htm>.

173. Alberta Rules, above n. 91, r 4.16 .

174. See Ibid., rr 4.18-4.21; See 'Judicial Dispute Resolution (Alberta)' (2015), available at: <www.justice.gc.ca/eng/fl-df/fjs-sjf/view-affic. asp?uid=88>

175. Ibid

176. Farrow, above n. 5, at 98-9. But see Hon H.F. Landerkin and A.J. Pirie, 'Judges as Mediators: What's the Problem with Judicial Dispute Resolution in Canada', 82 Canadian Bar Review 249 (2003). See also Ontario Bar Association Judicial Mediation Taskforce, A Different 'Day in Court': The Role of the Judiciary in Facilitating Settlements (Toronto: OBA) (2013), available at: <www.oba.org/getattachment/News-Media/ News/2013/July-2013/A-Different-'Day-in-Court-The-Role-of-theJudiciar/ADifferentDaylnCourt7122013.pdf>; N. Aylwin and T.C.W Farrow, "'A Different Day in Court": Exploring the Place of Judicial Mediation in Ontario's Alternative Dispute Resolution Landscape', 3 Journal of Civil Litigation and Practice 122 (2014)
JDR, is also available to litigants in Manitoba. ${ }^{177}$ Participation in this programme is voluntary, ${ }^{178}$ but it too has been a success. According to one lawyer, '[c]ivil litigation matters are [now] three-to-four times more likely to proceed to JADR than to trial'. ${ }^{179}$

Taken together, these court-sanctioned and court-based ADR programmes have fundamentally altered the process of litigation in Canada. Their emphasis on early dispute resolution has kept many cases from proceeding to trial and has placed professional obligations on lawyers to settle cases as soon as practicable. ${ }^{180}$ Although these ADR programmes have been widespread and successful, expediting resolution of matters and lowering costs for litigants, they have also led to a partial privatisation of the civil justice. In Hryniak, the Supreme Court wrote that 'without an accessible public forum for the adjudication of disputes, the rule of law is threatened and the development of the common law undermined'. ${ }^{181}$ It is essential that these pre-trial ADR procedures do not usurp the role of public courts, preventing important cases from public adjudication. ${ }^{182}$

\section{Conclusion}

In this article, we have outlined some of the Canadian challenges to access to justice and the procedures in place to simplify and reduce the costs of civil justice. In our review of existing empirical data, recent governmental austerity measures have not directly driven reform in Canada (although an overall lack of public funding is clearly a major impediment to meaningful civil justice reform capacity). More empirical data are needed to strengthen our observations. As Canadian civil justice reformers continue to organise and collaborate on a national level, an important ongoing project must be to collect more data. Without further data, progress in meaningful civil and access to justice innovation and reform will be slow and will lack the sophisticated evidence-based understandings that are required for lasting and meaningful change.

Rising legal costs and delays in civil justice have created a gap between the need for legal services and the affordability of those services. This 'gap' has been driving more of the court and legislative initiatives in Canada. This is a 'gap' that also pre-dated the recent world eco-

177. 'Manitoba Judicially Assisted Dispute Resolution (JADR)', 8 August 2012, available at: <www.cfcj-fcjc.org/inventory-of-reforms/manitobajudicially-assisted-dispute-resolution-jadr>

178. All that is required is a pre-trial conference. See Manitoba Rules, above n. $61, \mathrm{r} 50.01$.

179. G.A. Derwin, 'Judicially Assisted Dispute Resolution: Ten Years of Success', CBA ADR Newsletter, April 2008, available at: <www.cba.org/ $\mathrm{cba} /$ newsletters/adr-2008/news.aspx\#article3>

180. See e.g. Federation of Law Societies of Canada, Model Code of Professional Conduct, 10 October 2014, s 3.2-4 ('A lawyer must advise and encourage a client to compromise or settle a dispute whenever it is possible to do so on a reasonable basis...').

181. Hryniak, above n. 9, para. 26.

182. For further discussion of this concern, see Farrow, Civil Justice, above n. 5. 
nomic challenges (although, of course, those challenges have not helped funding in this area). However, it is clear that access to justice challenges are continuing to grow, and there is a widely held view that immediate action on this front is needed.

Despite the absence of jurisdictional uniformity in Canada, many jurisdictions have recently implemented programmes in response to this widely held and growing concern with a view to addressing the access to justice crisis. Robust simplified procedures and access to early ADR have been successful and generally popular across the county. Some of these procedures are still in their infancy or early adolescence, and only time will tell if they can inspire major change in the delivery of civil justice. More time will also be needed to study the impacts of these programmes more closely - both in terms of their immediate efficiency-based and other merits (often, although not always, involving cost and time savings as well as party autonomy and control), and in terms of their potential negative implications (potential lack of transparency and a negative impact on the development of public accountability and precedent). ${ }^{183}$ The Action Committee, led by Justice Thomas Cromwell of the Supreme Court of Canada, released an ambitious report outlining a collaborative and national vision for civil and family justice reform. ${ }^{184}$ This report includes a clear acknowledgement of Canada's growing access to justice crisis, the basis for a significant culture shift in the justice sector, and a specific set of concrete recommendations for the future of reform. Of course, the long-term impact of the Action Committee will largely depend on whether actors across the provinces and territories can come together to implement the report's recommendations (early indicators are very positive). With divergent civil jurisdictions and systems, national projects are always difficult to execute in Canada. Much depends on local efforts and projects. Legal service providers - lawyers, paralegals, and potentially other groups and forms of professionals and services will also need to pay more attention on these important access to justice challenges and opportunities. ${ }^{185}$ Yet, the current initiatives across the country, as well as new ideas such as British Columbia's online Civil Resolution Tribunal and the development of new centres for justice innovation, ${ }^{186}$ provide hope that Canada will be able to simplify, expedite, and increase access to civil justice in meaningful ways over the coming years. All signs are pointing in the right direction.

183. For recent and extensive commentary, debate and analysis on these issues, see Farrow, Civil Justice, above n. 5.

184. See Action Committee on Access to Justice in Civil and Family Matters, above n. 8. For a discussion of the Action Committee's work and its potential future impact, see T.C.W. Farrow, 'A New Wave of Access to Justice Reform in Canada', in A. Dodek and A. Woolley (eds.), In Search of the Ethical Lawyer (Vancouver: UBC Press) (2016), c. 8.

185. See e.g. the Law Society of Upper Canada's 2015-2019 strategic plan, Focused on the Future, which includes 'enhance access to justice...' as one of its five core strategic mandates, available at: <www.lsuc.on.ca/ strategic-plan/>. See further Action Committee on Access to Justice in Civil and Family Matters, above n. 8, at 14-5.

186. See e.g. the recently created Winkler Institute for Dispute Resolution at Osgoode Hall Law School in Toronto, available at: <http:// winklerinstitute.ca/>. 